\title{
Penerapan Lesson Study pada Kegiatan Praktikum Mikrobiologi Program Studi Pendidikan Biologi IKIP Budi Utomo Malang
}

\author{
TRIO AGENG PRAYITNO*, NURIL HIDAYATI \\ IKIP Budi Utomo, Jl. Simpang Arjuno No. 14B, Malang, Indonesia \\ *email: trioageng@gmail.com
}

Manuscript received: 20 Oktober 2015 Revision accepted: 5 Januari 2016

\begin{abstract}
Microbiology course is one of the compulsory subjects in the study program of education. This course requires implemented in two activities that is theory and practical. Limitations of equipment and materials in practical activities, the lack of detailed practical instructions for each topic, as well as the implementation of lab activities less systematically make this activity less than optimal. The development of psychomotor abilities and performance of students who are less maximized become another problem related to the achievement of learning objectives in accordance with the standards of competence in this course. Based on the above problems the researchers conducted a study on lab activities based lesson study. Selection of lesson study is done to correct deficiencies in each study appears from some observers and colleagues who participated in the activities of lesson study. Results from this study that practical activities based lesson study is able to improve the quality of learning and improving biology education students psychomotor ability at IKIP Budi Utomo Malang
\end{abstract}

Keywords: practical, lesson study, microbiology

\section{PENDAHULUAN}

Pembelajaran biologi tidak terlepas dari kegiatan praktikum selain kegiatan teori yang dilakukan di dalam kelas. Matakuliah Mikrobiologi merupakan salah satu matakuliah yang menuntut pembelajarannya dilakukan secara teori dan praktikum. Standar kompetensi pada matakuliah ini mencakup deskripsi dan pemahaman terkait mikrobiologi serta terampil dalam melakukan praktikum yang berkaitan dengan konsep yang dipelajari.

Hasil observasi yang dilakukan pada matakuliah mikrobiologi yakni praktikum dilakukan tanpa melihat keruntutan materi yang harus dibahas. Kegiatan praktikum cenderung dilakukan ketika alat dan bahan tersedia di laboratorium karena tidak semua alat dan bahan praktikum bisa didapatkan di laboratorium. Hal tersebut menjadi salah satu kendala dalam pelaksanaan kegiatan praktikum mikrobiologi.

Pada kegiatan praktikum, mahasiswa terlihat kurang serius dalam melakukan praktikum. Hal ini terlihat pada saat bekerja kelompok, yaitu beberapa mahasiswa tidak memahami apa yang harus dilakukan pada saat praktikum. Kegiatan praktikum juga belum dilengkapi dengan petunjuk instruksional praktikum.

Berdasarkan permasalahan yang ditemui tersebut, maka dirasa perlu dilakukan perbaikan konsep praktikum yang akan diberikan kepada mahasiswa terkait kurang tersedianya alat dan bahan yang digunakan dalam praktikum. Salah satu alternatif yang ditawarkan adalah dengan melakukan pembelajaran pada kegiatan praktikum berbasis lesson study. Lesson study merupakan sebuah pendekatan untuk melakukan perbaikan-perbaikan pada proses pembelajaran (Rokhmawati, 2011). Susilo (2013) menambahkan lesson study dapat diartikan sebagai model pembinaan bagi pendidik melalui pengkajian dan perbaikan pembelajaran yang sudah dilakukan agar menjadi lebih baik secara kolaboratif dan berkelanjutan, berdasarkan prinsip-prinsip kesejawatan dan mutul learning untuk membangun komunitas belajar. Perbaikan itu dilakukan dengan berkolaborasi antar para guru, sehingga diharapkan dengan penerapan lesson study akan mampu mengembangkan kegiatan praktikum mikrobiologi yang lebih terencana dan sesuai dengan kondisi laboratorium serta karakter mahasiswa Program Studi Pendidikan Biologi IKIP Budi Utomo. Dengan demikian, melalui kegiatan lesson study akan mendapatkan banyak informasi terkait kekurangan dan kelebihan selama pembelajaran khususnya kegiatan praktikum mikrobiologi yang pada akhirnya digunakan dalam perbaikan pada kegiatankegiatan praktikum mikrobiologi yang akan dilakukan pada pertemuan selanjutnya.

\section{METODE}

Pendekatan penelitian yang digunakan adalah pendekatan metode deskriptif kualitatif. Lesson study terdiri atas tiga tahap yakni plan, do, dan see. Lesson Study memiliki tahapan-tahapan yang perlu dilaksanakan secara sistematis, menurut versi yang dikembangkan FMIPA UNY bekerjasama dengan JICA terdiri dari tiga tahapan, yaitu : tahap perencanaan (plan), tahap pelaksanaan (do) yang sering disebut dengan research lesson dan tahap refleksi (see) atau kegiatan pasca pelajaran (Kadarisman, 2009). Tiga tahapan ini merupakan satu siklus pembelajaran. Pada penelitian ini ketiga tahap tersebut dilakukan pada tiap topik praktikum yang akan dipraktikumkan. Pada penelitian ini, peneliti berperan sebagai perancang kegiatan bersama dengan kolega, pengumpul data, dan penganalisis data. Penelitian dilakukan pada Semester Ganjil Tahun Ajaran 2015/2016 di Program Studi Pendidikan Biologi IKIP Budi Utomo Malang. Subjek penelitian adalah kelas B angkatan 2013 yang berjumlah 30 mahasiswa. 
Prosedur penelitian terdiri atas dua siklus. Pada tiap siklus fase pertama adalah tahap plan, peneliti membuat rancangan pembelajaran yang meliputi Rencana Pelaksanaan Pembelajaran (RPP), petunjuk praktikum, soal tes, pemilihan metode, menyiapkan lembar plan, lembar do, dan lembar see. Fese kedua adalah do dimana peneliti/ Dosen model melakukan pembelajaran melalui kegiatan praktikum sesuai dengan yang direncanakan pada tahap plan dan beberapa observer yang mengamati kegiatan pembelajaran yang terjadi. Fase ketiga adalah see, dimana akan didapatkan informasi dari observer pada saat fase $d o$. Selanjutnya informasi itu akan dijadikan sebagai bahan perbaikan pada siklus berikutnya. Tahapan tersebut juga dilakukan pada siklus kedua pada kegiatan praktikum yang akan dilakukan. Kegiatan praktikum dilakukan 3 x 50 menit untuk tiap pertemuan. Siklus lesson study dapat dilihat pada Gambar 1 di bawah ini.

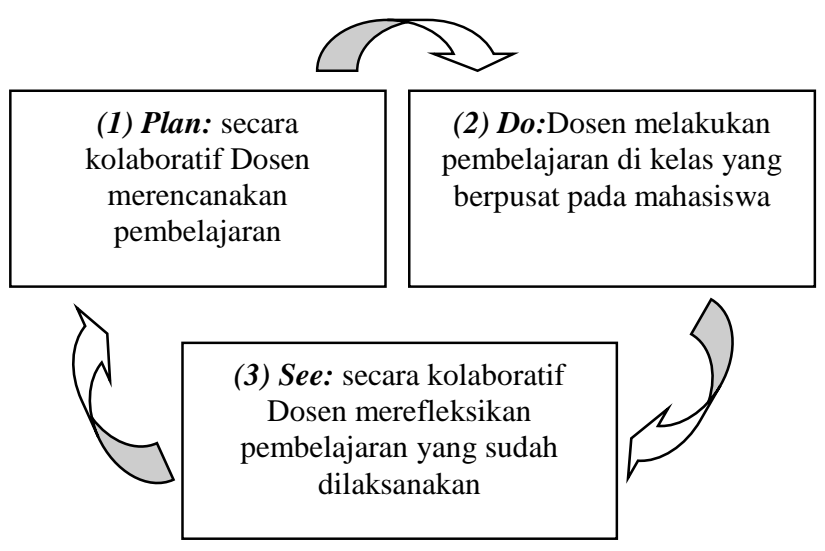

Gambar 1. Siklus Lesson Study (Sumber: Susilo, 2013)

Instrumen penelitian yang digunakan antara lain catatan lapangan, lembar observasi plan, do, dan see, dan soal tes pada tiap akhir siklus. Prosedur pengumpulan data meliputi observasi untuk merekam segala informasi pada kegiatan praktikum di kelas, tes sebagai alat ukur untuk mengetahui kemampuan psikomotor mahasiswa, catatan lapangan dan dokumentasi foto. Teknik analisis data hasil belajar psikomotor menggunakan rumus sebagai berikut.

$$
\begin{aligned}
& \text { Hasil belajar }=\sum \text { skor yang diperoleh tiap siswa } X 100 \\
& \sum \text { total skor }
\end{aligned}
$$

(Arikunto, 1998: 32)

\section{HASIL DAN ANALISIS DATA}

\section{Deskripsi Pelaksaanaan Lesson Study}

Pelaksanaan lesson Study pada siklus pertama dilakukan pada kegiatan praktikum dengan tema pembuatan medium mikroba. Perangkat pembelajaran yang meliputi RPP, lembar petunjuk praktikum, tes psikomotor mahasiswa, dan lembar kegiatan plan telah disusun sebelum kegiatan plan. Plan diikuti oleh peneliti dan beberapa kolega peneliti yakni lima Dosen pendidikan Biologi IKIP Budi Utomo Malang antara lain; Erfitra Rezqi Prasmala, Primadya Anantyarta, Ismi Nurul Qomariyah, Selvi Ariyunita, dan
Nuril Hidayati. Plan dilakukan di ruang Dosen Program Studi Pendidikan Biologi IKIP Budi Utomo Malang.

Kegiatan pertama yang dilakukan adalah terkait perencaan pelaksanaan kegiatan praktikum dengan topik pembuatan medium yang akan dilakukan. Plan dilakukan dengan membahas rencana pelaksanaan pembelajaran yang sebelumnya telah dirancang oleh Dosen model. Dosen model dan kolega membahas tentang keterkaitan antara standar kompetensi, kompetensi dasar serta kegiatan yang akan dilakukan yang tertuang pada RPP. Plan mendiskusikan bagaimana tahap apesepsi diberikan ketika praktikum sehingga mampu menstimulus mahasiswa untuk tertarik dan memahami apa yang akan mereka lakukan.

Model pembelajaran juga didiskusikan, Dosen model memilih metode demonstrasi karena sebagian besar mahasiswa belum mengetahui prosedur pelaksanaan praktikum mikrobiologi yang harus ekstra hati-hati dan steril. Bahwasanya demonstrasi akan memudahkan mahasiswa memahami prosedur dan mengetahui hal yang harus diperhatikan. Pada tahap ini diperoleh berbagai informasi terkait persiapan praktikum antara lain bahwa alat dan bahan pada kegiatan praktikum yang kurang tersedia di laboratorium sehingga dilakukan penggantian bahan praktikum yang awalnya akan membuat medium PDA (sintetis) tetapi bahan tersebut tidak tersedia di laboratorium sehingga diganti dengan menggunakan bahan ketang, dekstrosa, agar, dan aquades untuk membuat medium PDA (alami).

Alasan penggantian bahan tersebut bahwa kegiatan praktikum untuk topik pertama sangat penting untuk keberlanjutan kegiatan praktikum berikutnya sehingga praktikum pembuatan medium harus dilakukan dengan menggunakan bahan yang sederhana dan dapat ditemukan dengan mudah oleh mahasiswa untuk mengganti bahan medium yang dikomersilkan. Kendala kedua yang ditemukan pada saat plan adalah otoklaf yang akan digunakan tidak bisa digunakan karena rusak oleh karena itu penggantian otoklaf dilakukan dengan menggunakan panci bersekat yang memiliki fungsi yang hampir sama dengan otoklaf untuk mensterilkan alat dan bahan yang digunakan untuk pembuatan medium.

Kegiatan plan juga membahas terkait pembagian dan kerja tiap kelompok untuk memaksimalkan kerja mahasiswa mengingat alat dan bahan yang dimiliki terbatas untuk tiap kelompok. Penggantian bahan pembuatan medium akan berpengaruh pada petunjuk praktikum yang telah dibuat sehingga akan dilakukan perubahan pada alat, bahan, dan prosedur praktikum pembuatan medium. Pembuatan medium yang dilakukan lebih dari 1 yakni medium padat (PDA) dan medium cair (PD) sehingga untuk optimalisasi kinerja mahasiswa maka dilakukan pembagian untuk kelompok ganjil akan membuat medium padat sedangkan kelompok genap akan membuat medium cair. Pembahasan selanjutnya mengenai evaluasi yang digunakan untuk mengukur psikomotor mahasiswa dan dengan memperhatikan jumlah observer yang tidak sebanyak jumlah kelompok di dalam kelas, sehingga hal itu melandasi penggunaan tes tulis untuk memudahkan akses evaluasinya. Dengan berbagai informasi yang diperoleh 
pada saat plan maka banyak hal yang harus dirubah sebelum kegiatan Do di kelas.

Do dilakukan pada hari rabu jam 08.00 - 10.40 di Laboratorium Pend. Biologi IKIP Budi Utomo Malang. Dosen model adalah Trio Ageng Prayitno, Observer antara lain; Nuril Hidayati dan Selvi Ariyunita. Observer yang hadir hanya sedikit hal ini disebabkan jam mengajar Dosen selaku observer bentrok dengan kegiatan praktikum. Secara umum kegiatan praktikum berjalan dengan baik pada awalnya, mahasiswa tertarik dengan apersepsi yang dijelaskan oleh Dosen model dan mengikuti apa yang diinstruksikan oleh Dosen model sambil mendemonstrasikan mekanisme pembuatan medium mikroba.

Namun pada saat akan dilakukan praktikum mahasiswa terlihat menggerombol menjadi satu untuk melihat pembuatan medium. Hal ini disebabkan mahasiswa berebut untuk menggunakan alat (karena alat yang tersedia terbatas), sehingga mahasiswa yang tidak bisa menyaksikan tahap-tahap praktikum memilih untuk duduk dibelakang dan mengobrol dengan temannya. Hal ini tidak terlihat oleh Dosen model, sehingga tidak bisa memperhatikan mahasiswa yang tidak mengikuti praktikum tersebut. Pada saat praktikum beberapa mahasiswa terlihat melakukan kesalahan prosedur pencampuran bahan untuk membuat medium. Mahasiswa terlihat sering menggunakan ponsel untuk berfoto. Pada saat evaluasi masih ada mahasiswa yang mencontek. Pada keesokan harinya mahasiswa diinstruksikan untuk menangkap mikroba di sekitar kampus.

See dilakukan setelah kegiatan Do berakhir di Laboratorium. Hasil yang diperoleh adalah banyak hal yang menjadi bahan kajian yakni terkait alat dan bahan yang digunakan, kurang kehati-hatian mahasiswa dalam membaca petunjuk sehingga terjadi kesalahan prosedur dalam pembuatan medium. Mobilitas Dosen model hanya pada mahasiswa yang berada di depan yang melakukan kegiatan praktikum, sedangkan mahasiswa yang tidak melakukan praktikum tidak terlihat karena posisinya terhalangi oleh mahasiswa yang berada di depan, sehingga Dosen model tidak bisa menegur atau memperingatkan mahasiswa untuk serius praktikum.

Berdasarkan hal tersebut beberapa poin penting yang diperoleh adalah dilakukan penggantian tempat alat dan bahan pada meja yang paling tengah agar mahasiswa bisa memperhatikan dan melekukan praktikum dengan baik karena memiliki tempat dan ruang yang cukup untuk praktikum. Hal ini dilakukan untuk meminimalisir mahasiswa yang tidak memperhatikan serta serius dalam praktikum. Teguran yang tegas bagi mahasiswa yang bermain ponsel untuk berfoto agar mahasiswa tetap fokus dan serius praktikum. Dosen model harus waspada dalam menjaga mahasiswa ketika evaluasi agar hasil evaluasi dapat dipertanggungjawabkan dan tidak ada mahasiswa yang mencontek. Saran yang diperoleh pada tahap see digunakan untuk perbaikan pada saat plan siklus yang kedua. Rata-rata hasil belajar psikomotor mahasiswa pada kegiatan praktikum yang pertama dengan topik pembuatan medium mikroba adalah sebesar 93,33. Hasil ini diperoleh dengan baik karena mahasiswa bisa belajar langsung terkait konsep dan keterampilan pada saat praktikum. Kegiatan praktikum juga menjelaskan teori yang selama ini dipelajari oleh mahasiswa di kelas teori. Data hasil belajar psikomotor mahasiswa pada kegiatan praktikum mikrobiologi dapat dilihat pada Tabel 1.

Plan pada siklus kedua dilakukan di ruang Dosen Prodi Pendidikan Biologi IKIP Budi Utomo malang yang diikuti oleh Trio Ageng Prayitno selaku Dosen model, Selvi Ariyunita, Ismi Nurul Qomariyah, dan Nuril Hidayati.

Tabel 1. Data Hasil Belajar Psikomotor Mahasiswa pada Kegiatan Praktikum Mikrobiologi Siklus I

\begin{tabular}{llc}
\hline No & \multicolumn{1}{c}{ Nama Mahasiswa } & $\begin{array}{c}\text { Hasil Belajar } \\
\text { Psikomotor }\end{array}$ \\
\hline 1 & Yohana Wilhelmina K. & 100 \\
2 & Yohanes C.N. Samhafi & 0 \\
3 & Linda Fatmasari & 66,7 \\
4 & Yeni Ferdiana Lende & 50 \\
5 & Endang S. & 50 \\
6 & Aleksius Lamunde & 50 \\
7 & Emiliana Senia & 16,7 \\
8 & Paulina Bili & 33,3 \\
9 & Ria Oktavia & 33,3 \\
10 & Jumiati Gali & 50 \\
11 & Agustinus J. Kalaga & 50 \\
12 & Rikardus Sudi & 0 \\
13 & Sakarias Kalumbang & 66,7 \\
14 & Theresia Margareta Nunu & 83,3 \\
15 & Wilfridus Ola Balaweling & 66,7 \\
16 & Yanuarius Edulu & 50 \\
17 & Albertina Rambu Lenda & 66,7 \\
18 & Taufik Saidi & 50 \\
19 & Magdalena Lende & 50 \\
20 & Benyamin Kondora & 33,3 \\
21 & Patrik Alya Simson Bili & 50 \\
22 & Yanti Ardila & 66,7 \\
23 & Akvila Weni & 100 \\
24 & Magdalena G. Das Neves & 83,3 \\
25 & Florianus Sobu Sudi & 33,3 \\
26 & Reski Diantary & 100 \\
27 & Agnes Kodi Mete & 83,3 \\
28 & Yohanes H. Nampong & 33,3 \\
29 & Herminingsih Sulastri E.A & 50 \\
30 & Makarius Manca & 50 \\
Rata-Rata Hasil Belajar Psikomotor & $\mathbf{9 3 , 3 3}$ \\
\hline & &
\end{tabular}

Pada tahap ini perangkat pembelajaran, petunjuk praktikum, alat evaluasi dan lembar observasi lesson study sudah dipersiapkan. Diskusi apersepsi dilakukan untuk membuat mahasiswa fokus pada saat praktikum. perancangan desain peletakan alat dan bahan praktikum yang berada di bagian tengah dari kelas serta memudahkan Dosen untuk mengakses kinerja mahasiswa. Pemberian teguran kepada mahasiswa bahwasanya tidak diperkenankan menggunakan ponsel lebih dari 1 untuk tiap kelompok dan ponsel yang digunakan hanya untuk merekam tahapan praktikum. Mahasiswa diharuskan melaporkan hasil praktikum dalam bentuk poster yang 
didalamnya terdapat foto kegiatan praktikum sehingga mahasiswa harus fokus, teliti, dan hati-hati.

Do pada siklus kedua dilakukan pukul 08.00 - $10.40 \mathrm{di}$ Laboratorium dengan topik pengamatan morfologi koloni bakteri, dimana seminggu sebelumnya mahasiswa harus menangkap bakteri terlebih dahulu sebelum melaksanakan praktikum hari ini. Pengamatan dapat dilakukan dengan menggunakan lup (kaca pembesar) dan mahasiswa terlihat serius dalam praktikum karena telah diberikan instruksi oleh Dosen model. Kegiatan praktikum yang kedua lebih kondusif dibandingkan dengan sebelumnya. Namun, masih terdapat beberapa mahasiswa yang bermalas-malasan dalam praktikum dengan tidak melakukan praktikum. Kegiatan selanjutnya adalah tes tulis dan diakiri dengan mahasiswa bergotong royong untuk membersihkan cawan petri dan tabung reaksi yang berisi medium dan biakan bakteri.

See dilakukan di laboratorium setelah kegiatan praktikum berakhir. Saran yang diberikan adalah perlu usaha yang keras untuk membiasakan mahasiswa fokus dan teliti dalam kegiatan praktikum. Karena beberapa mahasiswa masih terlihat tidak antusias dalam mengikuti praktikum. Namun, dengan instruksi bahwa setiap kelompok harus melaporkan hasil praktikum dalam bentuk poster dan dokumentasi menjadikan mahasiswa fokus untuk mendokumentasikan objek praktikum bukan lagi untuk berfoto dirinya sendiri. Hal yang dapat dipetik dari kedua kegiatan praktikum ini adalah perlu dilakukan membiasakan diri mahasiswa untuk terampil melakukan kegiatan praktikum dan tetap melakukan kegiatan praktikum walau alat dan bahan tidak tersedia namun bisa diganti dengan alat dan bahan sederhana selama itu bisa menginterpretasikan yang sama dengan yang diharapkan sebelumnya. Rata-rata hasil belajar psikomotor mahasiswa adalah sebesar 99,81. Data hasil belajar psikomotor mahasiswa pada kegiatan praktikum mikrobiologi dapat dilihat pada Tabel 2 di bawah ini.

Tabel 2. Data Hasil Belajar Psikomotor Mahasiswa pada Kegiatan Praktikum Mikrobiologi Siklus II

\begin{tabular}{llc}
\hline No & \multicolumn{1}{c}{ Nama Mahasiswa } & $\begin{array}{c}\text { Hasil Belajar } \\
\text { Psikomotor }\end{array}$ \\
\hline 1 & Yohana Wilhelmina K. & 83,3 \\
2 & Yohanes C.N. Samhafi & 66,7 \\
3 & Linda Fatmasari & 83,3 \\
4 & Yeni Ferdiana Lende & 41,7 \\
5 & Endang S. & 66,7 \\
6 & Aleksius Lamunde & 91,7 \\
7 & Emiliana Senia & 66,7 \\
8 & Paulina Bili & 75 \\
9 & Ria Oktavia & 75 \\
10 & Jumiati Gali & 50 \\
11 & Agustinus J. Kalaga & 83,3 \\
12 & Rikardus Sudi & 75 \\
13 & Sakarias Kalumbang & 58,3 \\
14 & Theresia Margareta Nunu & 83,3 \\
15 & Agustinus Radu Kaka & 41,7 \\
16 & Yanuarius Edulu & 75 \\
17 & Albertina Rambu Lenda & 75 \\
\hline & &
\end{tabular}

\begin{tabular}{llc}
\hline No & \multicolumn{1}{c}{ Nama Mahasiswa } & $\begin{array}{c}\text { Hasil Belajar } \\
\text { Psikomotor }\end{array}$ \\
\hline 18 & Taufik Saidi & 91,7 \\
19 & Magdalena Lende & 75 \\
20 & Benyamin Kondora & 100 \\
21 & Patrisia H. Daman & 83,3 \\
22 & Yanti Ardila & 75 \\
23 & Akvila Weni & 75 \\
24 & Magdalena G. Das Neves & 66,7 \\
25 & Sabinus Bera Maran & 75 \\
26 & Reski Diantary & 66,7 \\
27 & Agnes Kodi Mete & 50 \\
28 & Yohanes H. Nampong & 91,7 \\
29 & Herminingsih Sulastri E.A & 83,3 \\
30 & Makarius Manca & 25 \\
Rata-Rata Hasil Belajar Psikomotor & $\mathbf{9 9 , 8 1}$ \\
\hline
\end{tabular}

Perbandingan rata-rata hasil belajar psikomotor mahasiswa mikrobiologi dari siklus I dan II dapat dilihat pada Gambar 2 di bawah ini.

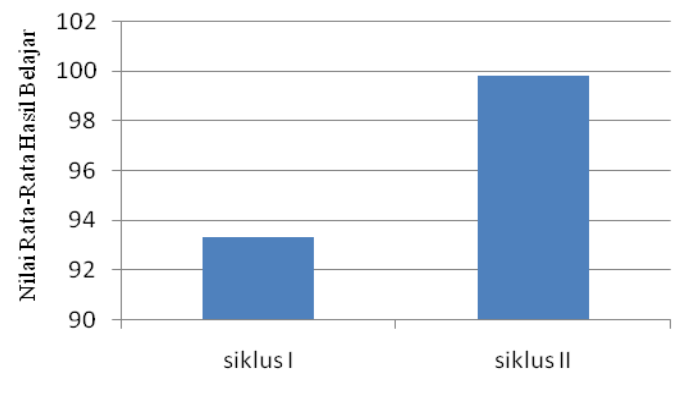

Hasil Belajar Psikomotor Mahasiswa

Gambar 2. Perbandingan Rata-rata Hasil Belajar Psikomotor Mahasiswa Mikrobiologi Siklus I dan II

Usaha perbaikan yang dilakukan dosen model dari siklus ke siklus seperti di atas merupakan kegiatan lesson study ialah cara dosen model untuk memperbaiki kelemahan-kelemahan dalam kegiatan pembelajarannya yakni kegiatan praktikum. Usaha itu dilakukan dengan meminta masukan dari kolega yang berlaku sebagai observer di kegiatan do yang dilakukan oleh dosen model. Pada siklus I terlihat jumlah anggota kelompok yang terlalu banyak. Tidak semua mahasiswa dapat melihat seluruh prosedur kegiatan praktikum karena setting tempat duduk yang kurang tepat. Kurangnya penjelasan tentang prosedur pengamatan kegiatan praktikum. Mahasiswa kurang dilibatkan dalam demostrasi praktikum sebelum pelaksanaan kegiatan praktikum dilaksanakan. Beberapa mahasiswa terlihat kurang aktif dalam kegiatan praktikum.

Kelemahan-kelemahan yang ditemukan Dosen model dan kolega (observer) seperti di atas, menambah motivasi Dosen model untuk memperbaikinya. Perbaikan yang dilakukan oleh Dosen model pada siklus II adalah jumlah anggota kelompok dibagi ulang menjadi kelompok yang proporsional sehingga memudahkan Dosen model dalam membimbingnya. Setting tempat duduk yang awalnya terlihat masih tersebar sendiri-sendiri dirubah menjadi tempat duduk melingkar yang di tengah-tengahnya ada 2 meja praktikum mahasiswa, sehingga memungkinkan 
semua mahasiswa dapat malihat dan menggunakan alat dan bahan dalam kegitan praktikum. Dosen model meminta kepada beberapa mahasiswa (secara bergantian) untuk menyiapkan dan membantu pelaksaanan demostraksi praktikum sehingga semua mahasiswa akan mengetahui dengan baik alat dan bahan yang digunakan dalam kegiatan praktikum. Setiap ada mahasiswa yang kurang aktif, maka Dosen model cepat-cepat mendatanginya untuk memberikan pengutan dan bimbingan agar mereka kembali aktif dalam kegiatan praktikum. Dengan demikian, adanya perbaikan di atas akan mengurangi kebingungan dan kesulitan mahasiswa dalam melaksanakan kegiatan praktikum secara utuh. Berkurangnya kebingungan dan kesulitan yang dialami oleh mahasiswa akan mempermudah mereka dalam melakukan unjuk kerja (psikomotorik) di dalam melaksanakan kegiatan praktikum.

Pernyataan di atas sesuai dengan pernyataan Susilo (2011) yakni lesson study adalah salah satu kegiatan untuk meningkatkan kualitas pembelajaran melalui kegiatan kolaboratif bersama kolega. Syamsuri dan Ibrohim (2008) juga menambahkan dalam penerapan lesson study guru berusaha untuk mengubah proses pembelajarannya menjadi menjadi proses pembelajaran yang berkualiatas dan efektif, dengan jalan mengamati dan pengumpulan data, melihat bagaimana dampaknya yang dibantu oleh kolega (observer), dan selanjutnya merevisi rencana pembelajaran untuk kegiatan pembelajaran berikutnya. Hendayana (2006) menjelaskan kegiatan lesson study adalah model pembinaan bagi guru melalui pengkajian pembelajaran secara kolaboratif dan berkelanjutan berlandaskan prinsip-prinsip kolegalitas dan mutual learning untuk membangun komunitas belajar. Sehingga lesson study merupakan cara peningkatan kualitas pembelajaran yang tidak pernah terputus.

Hasil pengamatan yang dilakukan oleh para observer menunjukkan bahwa dengan menggunakan lesson study kegiatan praktikum mikrobiologi semakin "hidup" karena mahasiswa ikut melakukan kegiatan secara langsung dan dosen model hanya bertugas sebagai fasilitator saja. Keaktifan mahasiswa terlihat bertambah kuat, hal itu ditunjukkan oleh mahasiswa yang sangat antusias untuk melakukan tahap demi tahap dari kegiatan praktikum yang sedang dilakukan. Pernyataan di atas sesuai dengan pendapat Santyasa (2009) yaitu adanya peningkatan perbaikan dalam praktik-praktik melaksankan pembelajaran tentunya akan bermuara pada peningkatan kualitas hasil belajar dan produk belajar mahasiswa.

Penerapan lesson study pada kegiatan praktikum dapat meningkatkan hasil belajar psikomotor mahasiswa dari siklus I ke siklus II yakni 93,33 ke 99,81. Kenaikan hasil belajar psikomotorik itu tidak terlepas dari usaha dosen model bersama dengan koleganya (observer) dalam memperbaiki proses pembelajarannya. Tahap demi tahap dosen model tidak henti-hentinya untuk memperbaiki rencana pembelajaran, memperbaiki cara mengajar, memberbaiki cara mengamati kegiatan mahasiswa, dan memperbaiki cara pemberian tes. Keseluruhan kegiatan tersebut dilakukan oleh dosen model demi meningkatkan kualitas pembelajaran yang dilakukannya. Pernyataan di atas didukung oleh pertanyaan Ibrohim (2009) bahwa kegiatan lesson study sebenarnya akan memberikan pengaruh terhadap hasil belajar siswa karena dalam kegiatan ini selalu dilakukan perbaikan-perbaikan dalam proses pembelajaran sehingga kesulitan-kesulitan yang dialami siswa akan teratasi dengan berjalannya kegiatan lesson study oleh guru. Garfield dalam Ibrohim dan Syamsuri (2008) juga menambahkan bahwa lesson study itu sebagai suatu proses yang sistematis yang digunakan oleh guru untuk menguji keefektifan pembelajarannya dalam rangka meningkatkan hasil pembelajarannya yang secara tidak langsung juga membantu dalam meningkatnya hasil belajar para siswanya.

Lewis (2005) menambahkan guru yang menerapkan lesson study akan menciptakan "multiple pathways of learning yang meningkatnya pengajaran yang dilakukan oleh guru, yakni; (1) guru selalu berusaha meningkatkan pengetahuan tentang bahan ajar, (2) pengetahuan tentang pengajaran, (3) kemampuan untuk mengamati siswa, (4) menguatkan jaringan kolegeal, dan (5) meningkatkan kualitas rencana pembelajaran. Lesson Study merupakan model peningkatan mutu pembelajaran melalui pengkajian pembelajaran secara kolaboratif dan berkelanjutan berlandaskan prinsip-prinsip kolegalitas dan mutual learning, untuk membangun learning community. Krisnawan (2010) menambahkan lesson study memberikan kesempatan nyata bagi guru untuk menyaksikan pembelajaran dan proses belajar siswa di ruang kelas. Lesson study ini juga membimbing guru untuk memfokuskan diskusi dengan kolega mengenai perencanaan, pelaksanaan, pengamatan, dan reflesi terkait praktik pembelajaran di kelas.

Keberhasilan penerapan lesson study pada penelitian ini tidak terlepas dari dukungan dari kolega (observer) saat berlangsungnya kegaitan pemebalajaran di kelas. Mereka melakukan pengamatan secara detail pada kegaitan mahasiswa dan bukan hanya kegiatan yang dilakukan oleh Dosen model. Sekecil apapun kegiatan mahasiswa dapat dicatat oleh kolega (observer), sehingga hasil dari pengamatan oleh observer dapat digunakan sebagai bahan perbaikan kualitas pembelajaran dan hasil belajar psikomotor mahasiswa mikrobiologi Program Studi Pendidikan Biologi IKIP Budi Utomo. Pertanyaan di atas sesuai dengan pernyataan Susilo (2013) bahwa observer itu punya rambu-rambu yakni; (1) tidak diperkenankan observer mengganggu siswa dan pendidik (mengajari siswa, berbicara sesama observer dan pendidik, memotret dengan menggunakan blitz), (2) posisi observer tidak mengganggu pandangan siswa atau guru model, observer harus bisa melihat wajah siswa dan observer dapat mendekat pada siswa (tanpa harus menyentuh siswa), (3) tidak diperkenankan keluar masuk kelas, (4) tidak diperkenankan duduk-duduk saja, (5) mencatat kegiatan siswa, bukan hanya kegiatan guru: kapankah siswa mulai konsentrasi dan apa penyebabnya, bagaimana interaksi siswa dengan siswa atau siswa dengan pendidik atau siswa dengan bahan ajar. 


\section{KESIMPULAN}

Kesimpulan dari hasil penelitian ini adalah kegiatan praktikum berbasis lesson study mampu mengembangkan dan meningkatkan kemampuan psikomotorik mahasiswa pada matakuliah mikrobiologi. Lesson study memberikan peluang untuk mendapatkan informasi dari berbagai sudut pandang kegiatan pembelajaran sehingga mampu memperbaiki pembelajaran.

\section{UCAPAN TERIMA KASIH}

Ucapan terima kasih disampaikan kepada para observer dan kolega peneliti yang sudah berperan aktif dan berpartisipasi dalam kegiatan lesson study dalam praktikum matakuliah Mikrobiologi

\section{REFERENSI}

Arikunto, S. (1998). Prosedur Penelitian (Suatu Pendekatan Praktik). Jakarta: Rineka Cipta.

Hendayana, S. (2006). Lesson Study: Suatu Strategi untuk Meningkatkan Keprofesionalan Pendidikan (Pengalaman IMSTEP-JICA). Bandung: UPI Press.

Ibrohim. (2009). Pengaruh Model Implementasi Lesson Study dalam Kegiatan MGMP terhadap Peningkatan Kompetensi Guru dan Hasil Belajar Biologi Siswa. Disertasi tidak diterbitkan. Malang: PPs UM.

Krisnawan, S.R. (2010). Penerapan Metode Lesson Study dalam Pembentukan Pendidikan yang Berkarakter. Disusun guna memenuhi Persyaratan Peserta Duta FKIP UNS. Surakarta: UNS.

Lewis, C. C. (2005). Lesson Study: A Handbook of Teacher-Led Instructional Change. Philadelphia. PA: research for better Schools,Inc.
Kadarisman, N. (2009). Teknik Dokumentasi dan Analisis Rekaman Video untuk Refleksi dalam Lesson Study. Makalah Deseminasi Lesson Study UNY. Diselenggarakan dalam rangka sosialisasi Lesson Study di Fakultas Lingkungan UNY.

Rokhmawati, A. (2011). Implementasi Praktik Pengalaman Lapangan (PPL) Berbasis Lesson Study untuk Meningkatkan Keterampilan Mahasiswa Pendidikan Biologi FMIPA UM dalam Memanfaatkan Media Pembelajaran dan Hasil Belajar Biologi Siswa SMA Negeri 9 Malang. Skripsi, Program Studi Pendidikan Biologi, Jurusan Biologi, Universitas Negeri Malang.

Santyasa, I. W. (2009). Implementasi Lesson Study dalam Pembelajaran. Disajikan dalam "Seminar Implementasi Lesson Study dalam Pembelajaran bagi Guru-Guru TK, Sekolah Dasar, dan Sekolah Menengah Pertama di Kecamatan Nusa Penida, Tanggal 24 Januari 2009. Universitas Pendidikan Ganesha.

Susilo, H. (2011). Pengembangan Potensi Siswa melalui Pembelajaran Sains yang Inovatif: Apa, Mengapa, dan Bagaimana?. Makalah disajikan dalam Seminar Nasional bertema Inovasi Pembelajaran Sains dalam Pengembangan Sumber Daya Manusia, Universitas Ronggolawe. Tuban, 22 Mei.

Susilo, H. (2013). Lesson Study Sebagai Sarana Meningkatkan Kompetensi Pendidik. Disajikan dalam Seminar dan Lokakarya PLEASE 2013 di Sekolah Tinggi Theologi Aletheia Jalan Argopuro 28-34 Lawang, Tanggal 9 Juli 2013. Syamsuri, I. \& Ibrohim. (2008). Lesson Study (Study Pembelajaran) Model Pembinaan Pendidik secara Kolaboratif dan Berkelanjutan; dipetik dari Program SISTTEMS-JICA di Kabupaten Pasuruan-Jawa Timur (20062008). Malang: FMIPA UM. 